\title{
Virgin microplastics are not causing imminent harm to fish after dietary exposure
}

\author{
Jovanovi, Boris; Gökda, Kerem; Güven, Olgaç; Emre, Yilmaz; Whitley, Elizabeth M.; Kideys, Ahmet
} Erkan

Published in:

Marine Pollution Bulletin

Link to article, DOI:

10.1016/j.marpolbul.2018.03.016

Publication date:

2018

Document Version

Peer reviewed version

Link back to DTU Orbit

Citation (APA):

Jovanovi, B., Gökda, K., Güven, O., Emre, Y., Whitley, E. M., \& Kideys, A. E. (2018). Virgin microplastics are not causing imminent harm to fish after dietary exposure. Marine Pollution Bulletin, 130, 123-131.

https://doi.org/10.1016/j.marpolbul.2018.03.016

\section{General rights}

Copyright and moral rights for the publications made accessible in the public portal are retained by the authors and/or other copyright owners and it is a condition of accessing publications that users recognise and abide by the legal requirements associated with these rights.

- Users may download and print one copy of any publication from the public portal for the purpose of private study or research.

- You may not further distribute the material or use it for any profit-making activity or commercial gain

- You may freely distribute the URL identifying the publication in the public portal 


\title{
Virgin microplastics are not causing imminent harm to fish after dietary exposure
}

\begin{abstract}
Among aquatic organisms, fish are particularly susceptible to ingesting microplastic particles due to their attractive coloration, buoyancy, and resemblance to food. However, in previous experimental setups, fish were usually exposed to unrealistically high concentrations of microplastics, or the microplastics were deliberately contaminated with persistent organic chemicals; also, in many experiments, the fish were exposed only during the larval stages. The present study investigated the effects of virgin microplastics in gilt-head seabream (Sparus aurata) after 45 days' exposure at $0.1 \mathrm{~g} \mathrm{~kg}-1$ bodyweight day- 1 to 6 common types of microplastics. The overall growth, biochemical analyses of the blood, histopathology, and the potential of the microplastics to accumulate in gastrointestinal organs or translocate to the liver and muscles were monitored and recorded. The results revealed that ingestion of virgin microplastics does not cause imminent harm to the adult gilt-head seabream during 45 days of exposure and an additional 30 days of depuration. The retention of virgin microplastics in the gastrointestinal tract was fairly low, indicating effective elimination of microplastics from the body of the fish and no significant accumulation after successive meals. Therefore, both the short- and the long-term retention potential of microplastics in the gastrointestinal tract of fish is close to zero. However, some large particles remained trapped in the liver, and $5.3 \%$ of all the livers analyzed contained at least one microplastic particle. In conclusion, the dietary exposure of S. aurata to 6 common types of virgin microplastics did not induce stress, alter the growth rate, cause pathology, or cause the microplastics to accumulate in the gastrointestinal tract of the fish.
\end{abstract}

Keywords

microplastics, marine litter, fish, histopathology, diet, toxicity

\section{Disciplines}

Ecology and Evolutionary Biology | Natural Resources Management and Policy | Terrestrial and Aquatic Ecology

\section{Comments}

This is a manuscript of an article published as Jovanović, Boris, Kerem Gökdağ, Olgaç Güven, Yilmaz Emre, Elizabeth M. Whitley, and Ahmet Erkan Kideys. "Virgin microplastics are not causing imminent harm to fish after dietary exposure." Marine pollution bulletin 130 (2018): 123-131. doi: 10.1016/j.marpolbul.2018.03.016. Posted with permission.

\section{Creative Commons License} (c) $(1) \Theta(9)$

This work is licensed under a Creative Commons Attribution-Noncommercial-No Derivative Works 4.0 License.

\section{Authors}

Boris Jovanović, Kerem Gökdağ, Olgaç Güven, Yilmaz Emre, Elizabeth M. Whitley, and Ahmet Erkan Kideys 


\section{Virgin microplastics are not causing imminent harm to fish after dietary exposure}

Boris Jovanović $^{\mathrm{a}, *}$, Kerem Gökdağ ${ }^{\mathrm{b}}$, Olgaç Güven ${ }^{\mathrm{b}}$, Yilmaz Emre ${ }^{\mathrm{c}}$, Elizabeth M. Whitley ${ }^{\mathrm{d}}$, Ahmet Erkan Kideys ${ }^{b}$

${ }^{a}$ Department of Natural Resource Ecology and Management, Iowa State University, Ames, IA, USA

' Institute of Marine Sciences, Middle East Technical University, Erdemli, Mersin, Turkey ${ }^{c}$ Faculty of Science, Akdeniz University, Antalya, Turkey

${ }^{d}$ Pathogenesis, LLC, Gainesville, FL, USA

\footnotetext{
* Corresponding author Boris Jovanović Iowa State University

Department of Natural Resource Ecology and Management 107 Science II 2310 Pammel Drive. Ames, IA, 50011, USA nanoaquatox@gmail.com
} 


\section{Abstract}

Among aquatic organisms, fish are particularly susceptible to ingesting microplastic particles due to their attractive coloration, buoyancy, and resemblance to food. However, in previous experimental setups, fish were usually exposed to unrealistically high concentrations of microplastics, or the microplastics were deliberately contaminated with persistent organic chemicals; also, in many experiments, the fish were exposed only during the larval stages. The present study investigated the effects of virgin microplastics in gilt-head seabream (Sparus aurata) after 45 days' exposure at $0.1 \mathrm{~g} \mathrm{~kg}^{-1}$ bodyweight day ${ }^{-1}$ to 6 common types of microplastics. The overall growth, biochemical analyses of the blood, histopathology, and the potential of the microplastics to accumulate in gastrointestinal organs or translocate to the liver and muscles were monitored and recorded. The results revealed that ingestion of virgin microplastics does not cause imminent harm to the adult gilt-head seabream during 45 days of exposure and an additional 30 days of depuration. The retention of virgin microplastics in the gastrointestinal tract was fairly low, indicating effective elimination of microplastics from the body of the fish and no significant accumulation after successive meals. Therefore, both the short- and the long-term retention potential of microplastics in the gastrointestinal tract of fish is close to zero. However, some large particles remained trapped in the liver, and $5.3 \%$ of all the livers analyzed contained at least one microplastic particle. In conclusion, the dietary exposure of S. aurata to 6 common types of virgin microplastics did not induce stress, alter the growth rate, cause pathology, or cause the microplastics to accumulate in the gastrointestinal tract of the fish.

Keywords: microplastics; marine litter; fish; histopathology; diet; toxicity. 


\section{Introduction}

Every year, between 4.8 and 12.7 million metric tons (MT) of plastic waste enters the ocean (Jambeck et al., 2015). In the last two decades plastic already outweighs plankton in certain parts of the ocean (Moore et al., 2001), and by 2050 it is expected that plastic will surpass fish stocks in the ocean by weight. In 2014 , the estimated number of floating plastic particles in the world's oceans was 5.25 trillion (269000 MT), out of which 4.85 trillion particles were microplastics of $<4.75 \mathrm{~mm}$ in size (Eriksen et al., 2014). The difference between the yearly plastic waste discharge into the ocean and the amount of floating plastic estimated by Eriksen and colleagues is perhaps because it has sunk below the surface, washed ashore onto beaches, or been ingested by marine animals. The average concentration of plastic for the whole ocean is estimated to be $2 \mathrm{ng} \mathrm{L}^{-1}$ (Koelmans et al., 2016), which may not look so significant. However, microplastics can reach a high concentration in specific areas. For example, the Swedish west coast harbor adjacent to a polyethylene factory has a microplastics concentration of 102000 particles $\mathrm{m}^{-3}$ (Lozano, 2009). With most of the microplastics particles weighing less than $0.01 \mathrm{~g}$ (MorétFerguson et al., 2010), or more specifically around $0.02 \mathrm{mg}$ (Gökdağ, 2017), in this extreme case, their concentration would be around $0.02-1 \mathrm{~g} \mathrm{~L}^{-1}$. Therefore, it is of no surprise that scientific literature on the topic of the potential toxic effects of microplastics on aquatic organisms is steadily growing. Microplastic exposure has been identified as having a negative effect on: growth, development, behavior, reproduction, intestinal blockage, physical damage, and the mortality of aquatic organisms (Chae and An, In press; Jovanović, 2017). However, in past experimental setups, organisms were usually exposed to microplastic concentrations which are unrealistically high and not environmentally relevant (Phuong et al., 2016). Furthermore, in dietary exposure studies microplastics are often deliberately contaminated with persistent organic chemicals in order to simulate their adsorption to microplastics in the aquatic environment (Batel 
et al., 2016; Rochman et al., 2013). Therefore, due to a high microplastic concentration, not only have such studies often been associated with great contaminant stress that does not necessarily occur in the natural environment (Phuong et al., 2016), but also the intrinsic toxicity information (if any) of virgin microplastics is lost. At least in the case of hydrophobic organic toxicants associated with microplastics, the ingestion of an environmentally relevant concentration of microplastics is not likely to increase exposure (and thus risk) to marine organisms (Koelmans et al., 2016). Among aquatic organisms, fish are particularly susceptible to the ingestion of microplastic particles due to their attractive coloration, buoyancy, and resemblance to food (Güven et al., 2017; Jovanović, 2017). In summary, although intestinal blockage, physical damage, histopathological alterations in the intestines, changes in behavior, changes in the lipid metabolism, and transfer to the liver are the observed effects of microplastic ingestion by fish, these effects are frequently observed in larval fish or in studies with high concentration of microplastics and/or contaminant laden microplastics (Jovanović, 2017). Therefore, the aim of the present study was to evaluate the effects of virgin microplastics in adult fish, Sparus aurata, Linnaeus, 1758, after 45 days of dietary exposure to environmentally relevant concentrations of 6 common types of microplastics. S. aurata was used in the present research, as it is one of the well studied model species in aquaculture (Grigorakis, 2007; Koven et al., 2001).

\section{Methods}

\section{Microplastics}

Six different types of microplastic particles were purchased from Sigma-Aldrich: 1) polyvinyl chloride high molecular weight (PVCHMW) - catalog number 81387; 2) polyamide (PA) - catalog number 02395; 3) ultra-high molecular weight polyethylene (UHMWPE) - catalog 
number 434272; 4) polystyrene (PS) - catalog number 430102; 5) average molecular weight medium density polyethylene (MDPE) - catalog number 427772; and 6) polyvinyl chloride low molecular weight (PWCLMW) - catalog number 81388. With the exception of PS all other products were used in the form in which they were received. PS microplastic spherical pellets were too big (approximately $2 \mathrm{~mm}$ in diameter) compared to the other products and were thus ground using a coffee grinder. In order to estimate the average size of each product, 50-100 particles were placed under a binocular scope and photos were taken. The Lapazz TWMM853 Graphic Tablet with ImageJ software was used to calculate the size of each particle.

\section{Fish and dietary exposure to microplastics}

$500 \mathrm{~L}$ tanks with a single pass water flow were used to house juvenile gilt-head seabream - S. aurata. Each of the 7 tanks had 50 fish to start with, which were acclimated for a week to the new housing environment before the start of the experiments. The $S$. aurata were bred in house at the Mediterranean Fisheries Research Production and Training Institute, Demre-Antalya-Turkey. Before placement in the tanks, each fish was weighed. The total biomass per tank ranged between $375.1 \mathrm{~g}$ and $377.4 \mathrm{~g}$. There was no statistical difference in the fish mass between any of the tanks. The mean mass of the fish \pm standard deviation (SD) in the 7 tanks was: $7.54 \pm 0.32 ; 7.55 \pm 0.31$; $7.53 \pm 0.31 ; 7.52 \pm 0.31 ; 7.53 \pm 0.32 ; 7.50 \pm 0.30 ;$ and $7.50 \pm 0.29 \mathrm{~g}$ in no particular order.

The 6 treatments and the control group were assigned randomly to the tanks. The treatments were: 1. PVCHMW; 2. PA; 3. UHMWPE; 4. PS; 5. MDPE; 6. PWCLMW; and 7. Control.

It is hard to say what the daily microplastic ingestion load of a fish is in its natural environment, as such studies do not exist (Jovanović, 2017). We assumed that the ingested microplastic content by fish per day would not exceed $0.3 \%$ of the total ingested daily feed, even 
in marine environments with a high microplastic concentration. The microplastics were mixed into the fish feed, and feed pellets were made at a concentration of $3.33 \mathrm{~g} \mathrm{~kg}^{-1}$ of feed. The pellets were $3.0 \mathrm{~mm}$ in size and were made with a cold extrusion machine. The pellets were dried in an oven at $40{ }^{\circ} \mathrm{C}$ for $24 \mathrm{~h}$ and stored in airtight bags until use. The approximate composition of the feed was: crude protein $48.66 \%$, crude lipid $18.54 \%$, crude ash $7.77 \%$, crude cellulose $1.27 \%$, total phosphorous $2.71 \%$ and crude starch $8.50 \%$. The fish were fed $3 \%$ of their body mass daily and were therefore exposed to the microplastics at approximately $0.1 \mathrm{~g} \mathrm{per} \mathrm{kg}^{-1}$ body mass. A control group of fish was fed with the same feed, only without the addition of microplastics. Since, initially, the fish weighed approximately $7.5 \mathrm{~g}$ and the microplastic particles in general were around $75 \mu \mathrm{m}$ in size, each fish at the start of the experiment could potentially ingest a maximum of $0.75 \mathrm{mg}$ of plastic or around 2800 particles per day. For this approximation, the particles were considered as a perfect sphere and the mass of a single microplastic particle was calculated accordingly as the mass of a sphere $\left(M=4 / 3 \pi \mathrm{r}^{3} \rho\right.$, where $r$ is assumed to be $0.0375 \mathrm{~mm}$ and $\rho$ is $1.2 \mathrm{mg} \mathrm{mm}^{-3}$ ). This is, however, only a rough approximation of the potential number of particles. In reality, the fish ingested a smaller number of particles per day as fish do have numerous adaptations for the exclusion of sediment from the buccal cavity and microplastic is likely not an exception. Therefore, in terms of particle concentration, mass, and number we believe that the present exposure scenario is environmentally relevant, and not an exaggeration.

The fish were fed for 45 days, starting June 18, 2015. The water temperature was recorded daily in each tank. There was no difference in the average daily temperature between the tanks and it was typically in the range of $25.7{ }^{\circ} \mathrm{C}$ to $25.8^{\circ} \mathrm{C}$. The maximum difference in the water temperature between any of the 2 tanks on the same day was no bigger than $0.2{ }^{\circ} \mathrm{C}$. Every two weeks, 10 random fish from each tank were netted and weighed in order to further adjust the daily amount of feed given ( $3 \%$ of body mass) if necessary. 
At the end of the feeding trial 3 random fish from each tank were euthanized, their blood was collected from the puncture of caudal vein using a syringe and collected into micro tubes $(0.5$ $\mathrm{mL}$ ). Levels of glucose, AST, ALT, LDH, and GGT were measured in serum of each fish using automated chemical analyzer.

24 hours after the last feeding, 15 random fish per tank were euthanized. First, a sample of the caudal muscles was taken, followed by a liver sample. In order to avoid contamination, the gastrointestinal tract was dissected only after the samples of muscles and liver were collected. The stomach, intestines, liver, and muscles samples were placed in $50 \mathrm{~mL}$ centrifuge tubes and treated with $30 \mathrm{~mL}$ of $4 \mathrm{M} \mathrm{KOH}$ for one hour at $60{ }^{\circ} \mathrm{C}$ in a water bath. After one hour, the samples were washed with distilled water and filtered through a $10 \mu \mathrm{m}$ zooplankton mesh. The microplastic particles were counted using an Olympus SZX16 Stereomicroscope (max magnification 30X) equipped with a DP26 - Olympus 5.0 MP High Color Fidelity Microscope Digital Camera. The photos were taken and processed using the Olympus cellSens platform (Image Analysis software) in order to determine the diameter/length of each particle individually.

Five random fish per tank were euthanized, and the ceolomic cavity of each fish was incised proximally from the anus, and fixed in $10 \%$ neutral buffered formalin for later histopathology analyses.

All of the remaining fish were fed with a controlled diet for the next 30 days. This was the depuration period. After the end of the depuration period, 15 random fish were euthanized and their gastrointestinal content was analyzed for the presence of microplastics as previously described above. The levels of glucose, AST, ALT, LDH, and GGT were also recorded in additional 3 random fish from each tank.

\section{Histopathology}


The fish were dissected to remove the ceolomic organs for histological processing. The samples were processed routinely into paraffin blocks, cut at 5 microns, stained with hematoxylin and eosin $(\mathrm{H} \& \mathrm{E})$ and examined microscopically under bright-field conditions. Any tissue and cytomorphologic changes in the gastrointestinal tract, liver, pancreas, spleen, and mesentery were recorded using a semi-quantitative severity scale (Table 1). Ceolomic organs were removed en bloc and sectioned and cassetted in order to get 10-19 sections of stomach/intestine on each slide. A list of the histopathological features analyzed is presented in Supporting Table S1.

\section{Statistical analyses}

All data were tested for normality with Kolmogorov-Smirnov and Shapiro-Wilk test. If data were normally distributed One-Way Analysis of Variance (ANOVA) with a post-hoc Dunnett's test was utilized, otherwise a non-parametric Kruskal-Wallis ANOVA, Mann-Whitney $\mathrm{U}$ test, and/or Wilcoxon matched pairs test were used for statistical comparison. P value of 0.05 was considered statistically significant for all analyses.

\section{Results}

Photos of the microplastics used in the dietary exposure are presented in Figure 1. The average size \pm standard deviation (SD) of the particles was: $75.6 \pm 15.3 \mu \mathrm{m}$ for PVCHMW; 111.7 $\pm 32.2 \mu \mathrm{m}$ for PA; $23.4 \pm 7.6 \mu \mathrm{m}$ for UHMWPE; $51.0 \pm 36.3$ for PS; $54.5 \pm 21.3 \mu \mathrm{m}$ for MDPE; and $87.6 \pm 16.8 \mu \mathrm{m}$ for PWCLMW.

The total biomass of the fish per tank was not influenced by the treatment and ranged between 635 - $680 \mathrm{~g}$ on day 15; 938 - $970 \mathrm{~g}$ on day 30; and 1312 - $1450 \mathrm{~g}$ on day 45. 
The levels of glucose, AST, ALT, LDH, and GGT are presented in Table 2. None of these parameters differed significantly when the control was compared to the treatments (Dunnett's test $p>0.05)$.

The retention rate of microplastics in the gastrointestinal tract was very low (Table 3). 24 hours after the last feeding the average number of microplastic particles in the fish intestines and stomachs ranged between 0 and 34 for all plastic types. Some of the individual fish obviously did not defecate (or had limited defecation) during the $24 \mathrm{~h}$ period as one individual from the PA group contained 10 microplastic particles in the stomach and 449 particles in the intestines, while another 2 individuals from the MDPE group contained 79 and 110 particles in the intestine (6 and 0 in the stomach). Statistical comparison showed that $24 \mathrm{~h}$ after the last feeding the retention of microplastics was significantly higher in the intestines than the stomach (Mann-Whitney U Test, $\mathrm{N}=180, p<0.05)$. There was a significant difference regarding the type of plastic retained in the intestines (Kruskal-Wallis ANOVA, $p<0.05$ ), but not in the stomach (Kruskal-Wallis ANOVA, $p>0.05)$. A follow-up multiple comparison of mean groups for the intestines revealed that more PA plastic was retained than PVCHMW. The other groups were not statistically different. After the 30-day depuration period the retention of microplastic particles in the gastrointestinal tract was even smaller (Wilcoxon matched pairs test, $p<0.05$ ) (Table 3), indicating that the long term retention potential of microplastics in the gastrointestinal tract of fish is close to zero. There was no statistical difference between the types of plastic retained in the intestines (Kruskal-Wallis ANOVA, $p>0.05)$. Some of the microplastic particles translocated to the liver and $5.3 \%$ of all the livers analyzed had microplastic inside them after $24 \mathrm{~h}$, while $1 \%$ (a single liver) had microplastic after the depuration period of 30 days (Table 3). However, this particular liver contained a high quantity of microplastic particles - 15 pieces (PVCHMW group). The average size of all microplastic particles found in the liver, irrespective of the plastic type, \pm SD was 214 
$\pm 288 \mu \mathrm{m}$. The translocation of a single microplastic particle to the caudal muscle in one fish was also detected.

\section{Histopathology}

When all of the scored histopathology features were combined together (Figure 2), there was no statistically significant difference in the average histopathology between the groups ( $p=$ 0.155, by ANOVA). After posthoc comparison of the control with the treatments using Dunnet's procedure there was no statistically significant difference for any of the comparisons. The only treatment which yielded a $\mathrm{p}$ value near the significance level when compared with the control was the PVCHMW treatment with a one-sided $\mathrm{p}$ value of 0.063 . However, the histopathology score was small and such small pathology features are expected in normal and healthy fish.

Minimal to mild infiltration of the lamina propria of the stomach and/or intestine were the most commonly observed changes, and they were observed in one or more fish in each treatment group and in the control group (Figures 3 and 4). The histopathology scores for leukocyte infiltration in the stomach or intestine were not significantly different among the groups (ANOVA; $p>0.05$ ). In the intestine there was no difference between the control and the treatments for the epithelial detachment, degeneration, necrosis or apoptosis, vacuolization, goblet cell hyperplasia, villous shortening or blunting, or lamina propria / serosa edema (Supporting Table S1).

In the liver, the hepatocytes contained variable amounts of clear space (consistent with the microscopic appearance of glycogen), which is considered normal (Figure 5). Adipocytes were often present surrounding some intrahepatic lobules of pancreatic tissue, and the mesentery contained moderate to abundant adipose tissue (considered normal findings). Discrete cells with the morphology of rodlet cells and/or macrophages were present around lobules of the 
intrahepatic pancreas and within the mesentery, with no apparent difference in the numbers of cells, morphology, or distribution between control and treatments. The acinar cells in the pancreata of each fish contained numerous eosinophilic granules, consistent with active zymogen production necessary for digestion (and, therefore, active consumption of food). In the case of the liver and pancreas, there was no statistical difference in histopathology between the control and treatments (Supporting Table S1).

In a single fish from the PA group, a very small focus of fibroplasia and granulomatous inflammation was present in the intestinal mesentery. The cause of this lesion was not identified.

\section{Discussion}

Microplastic translocation to the liver of various fish species has already been observed (Avio et al., 2015; Lu et al., 2016). However, translocation does not occur after every exposure. For example, carcasses of treatment fish were examined after microplastics laden dietary exposure but microplastics were not observed in any other organ apart from the gut tissue and gut contents (Grigorakis et al., 2017). In some of the mentioned experiments translocation induced certain negative effects in the liver, such as: inflammation, lipid accumulation, oxidative stress ( $\mathrm{Lu}$ et al., 2016), while in others no negative effects were observed in the liver (Avio et al., 2015). Disparity between having observed effects and no observed effects was mainly due to differences in the concentrations as one study used unrealistically high microplastic exposure concentrations of 4500 particles $\mathrm{mL}^{-1}-290000$ particles $\mathrm{mL}^{-1}$ (Lu et al., 2016). Exposure to such a high concentration of any kind of particles (if the particles are sufficiently small in size) will undoubtedly cause inflammation and oxidative stress in fish due to overstimulation of the innate immune system, frustrated phagocytosis, and changes in the function of the phagocytic cells (Jovanović and Palić, 2012). A more realistic exposure study with around 2500 particles $\mathrm{L}^{-1}$ did 
not report any negative effects in the liver (Avio et al., 2015). This concentration is similar to the exposure concentration of $0.1 \mathrm{~g} \mathrm{~kg}^{-1}$ body mass (potential 2800 particles per fish) in our present research, which also did not induce any apparent liver damage. The number of microplastic particles discovered in the fish livers was small, on average $<1$ particle. This falls in line with previous studies which discovered on average 1 microplastic particle per liver (Collard et al., 2017) or $1-2$ microplastic particles per liver (Avio et al., 2015). An exception to the 1 particle per liver rule is a study with the above mentioned high exposure concentration which demonstrated that fish liver is capable of storing (at least temporarily) approximately $1 \mu \mathrm{g}$ of plastics per $1 \mathrm{mg}$ of fish liver tissue (Lu et al., 2016), but only if the particles are sufficiently small: $<5 \mu \mathrm{m}$ in size. Particle size plays a major factor in determining the physiological process that governs translocation to the liver. For different vertebrate species, particles $<5 \mu \mathrm{m}$ in size may pass through the enterocyte cells via transcytosis, enter the circulatory system and travel to liver; while particles of $5-150 \mu \mathrm{m}$ in size may pass the intestinal mucosa through the vilus tips via the persorption process (Volkheimer, 1977) and again translocate to the liver with the help of the circulatory system. While the transcytosis of small particles may be a common process, the persorption of large particles is a rare process (O’Hagan, 1996). Small particles can easily be removed from the liver through the circulatory system while large particles, however, are more likely to remain. In the present research, we could not detect particles smaller than $10 \mu \mathrm{m}$ in size due to the methodological constraints, since the digested organs were filtered through a $10 \mu \mathrm{m}$ mesh. Therefore, all of the particles extracted from the liver likely arrived by the process of persorption. The average size of the particles present in the liver \pm SD was $214 \pm 288 \mu \mathrm{m}$. This is similar to the findings of other researchers: $323 \pm 101$ (Collard et al., 2017) and $200-600 \mu \mathrm{m}$ (Avio et al., 2015). Based on both the present and previous results it may be that the upper limit for persorption in fish is greater than the established $150 \mu \mathrm{m}$ limit in a variety of vertebrates, 
although unlikely. We are, however, not aware of any study that has specifically investigated the persorption size limit in fish. Translocation of microplastics across fish gut should be taken with caution since neither our study, nor any other fish study, investigated the mechanism of the passage of de facto plastic material across fish guts. In order for microplastics to reach the liver, an entry into the circulation via direct penetration of the vessel lining of endothelial cells would be a required route or a translocation of particles via the intestinal lymphatics before gaining entry to the portal system (Hussain et al., 2001). While translocation of ingested microplastics (< $10 \mu \mathrm{m}$ ) into the circulation system of the mussel Mytilus edulis was demonstrated (Browne et al., 2008) it could not be repeated in a closely related oyster (Sussarellu et al., 2016). Given the large diameter and low number of microplastics observed in liver, both in the present and in previous studies, a possibility of contamination should be considered carefully. However, the risk of sample contamination by hard plastics is not as high as the risk of contamination by fibers.

Retention of virgin microplastics in the gastrointestinal tract was fairly low, indicating the effective elimination of microplastics from the body of the fish and no significant accumulation after successive meals. Recently, another study investigated the gut retention of microplastics in goldfish (Grigorakis et al., 2017). It reported that the $50 \%$ and $90 \%$ evacuation times of microplastics from the goldfish gut are $10 \mathrm{~h}$ and $33.4 \mathrm{~h}$, respectively. This is very similar to the present research, as around $90 \%$ of gilt-head seabream had cleared the microplastics from their gastrointestinal tract (except for a few remaining particles) after $24 \mathrm{~h}$. Microbeads were also fully cleared from the gut of European seabass larvae $48 \mathrm{~h}$ after exposure (Mazurais et al., 2015), while microplastic particles were rapidly cleared and reached a steady state in the zebrafish gut $48 \mathrm{~h}$ after exposure ( $\mathrm{Lu}$ et al., 2016). Therefore, both the short- and the long-term accumulation potential of microplastics in the gastrointestinal tract of fish is close to zero. A recent study reported certain pathological alterations in the gut after exposure to a similar concentration of 
PVC microplastics as in the present study, such as widening of the lamnia propria, shortening and swelling of the vili, vacuolation of the enterocytes and an increase in rodlet cells after 90 days of exposure (Pedà et al., 2016). Similarly, exposure to 5 common types of microplastics, including PVC, caused intestinal damage - mainly cracking of villi and splitting of enterocytes in zebrafish (Lei et al., 2018). However, we did not detect a statistical difference between the PVC group and control at all while sharing the same pathological parameters with the previously mentioned study (Pedà et al., 2016), although the $\mathrm{p}$ value was close to significance (one sided $p=0.063$ ). However, the histopathology score was low and even if the PVC group was statistically different, such small pathological changes are expected in normal and healthy fish. No other microplastic groups were close to being significantly different when compared to the control. Since the exposure concentration was nearly the same in the previous and the present study, the discrepancy in the results may perhaps be explained by the duration of exposure, or the shape of microplastics. Exposure time in the previous study (i.e. Pedà et al., 2016) was 90 days while it was 45 days in the present study. A longer exposure in the previous study could have potentially aggravated the pathological changes in the fish gut. Furthermore, both previous studies (Lei et al., 2018; Pedà et al., 2016) were grinding microplastics before the exposure, which likely resulted in sharp edges and rough surface of the particles. In our present study, plastic particles were in the primary pellet/powder form, as made by manufacturer, and had a smoother surface without spiky edges. It was previously suggested that the smooth spherical shapes of microplastics could limit the tissue damage and facilitate their excretion in fish (Romano et al., In press).

The biochemical parameters in the blood were not significantly different between the control and treatments, indicating a lack of stress after the ingestion of microplastics. Similarly, a dietary exposure concentration to PVC microplastics that was five times higher $\left(0.5 \mathrm{~g} \mathrm{~kg}^{-1}\right)$ for 30 
days induced a small increase in the AST, albumin, and globulin levels of $S$. aurata, while the levels of glucose and other monitored parameters remained unchanged (Espinosa et al., 2017).

In conclusion, the dietary exposure of $S$. aurata for 45 days at $0.1 \mathrm{~g} \mathrm{~kg}^{-1}$ bodyweight day ${ }^{-1}$ to 6 common types of microplastics, followed by a 30-day depuration period, did not induce stress or an altered growth rate, did not cause pathology, and did not result in microplastic accumulation in the gastrointestinal tract of the fish. Translocation of microplastics was detected in the livers of few fish, however the rate was very small, on average $<1$ particle per liver. Possible mechanism of transport remains unknown. Such finding may be important from physiological perspective and calls for further targeted studies; however, its biological and toxicological significance is low as there is no potential for bioacumulation.

\section{Acknowledgments}

This research was supported by Scientific and Technological Research Council of Turkey (TUBITAK) grants; CAYDAG-114Y244 ("Estimating the quantity and composition of microplastics in the Mediterranean coast of Turkey; the potential for bioaccumulation in seafood") and CAYDAG-115Y627 ("Impacts of Microplastic Particles and Bisphenol A as a Chemical Additive in Zooplankton Species of Mersin Bay"). We wish to extend our gratitude to Mehmet Özalp of IMS-METU and Derya Güroy of Yalova University for the technical help with fish feed preparation and sample processing.

\section{Declaration of interest}

None

\section{Author contribution statement:}


$\mathrm{BJ}$ and $\mathrm{AEK}$ come with the original research idea and designed experimental setup. BJ wrote the paper and analyzed the results. KG and OG participated in microplastic extraction related experiments. YE participated in microplastic exposure experiments, feed preparation, and biochemical analyses of the blood. EMW performed histopathology examination. All authors commented on preliminary version of the manuscript and approved the final version of the manuscript.

\section{References}

Avio, C.G., Gorbi, S., Regoli, F., 2015. Experimental development of a new protocol for extraction and characterization of microplastics in fish tissues: First observations in commercial species from Adriatic Sea. Marine Environmental Research 111, 18-26.

Batel, A., Linti, F., Scherer, M., Erdinger, L., Braunbeck, T., 2016. Transfer of benzo[a]pyrene from microplastics to Artemia nauplii and further to zebrafish via a trophic food web experiment: CYP1A induction and visual tracking of persistent organic pollutants. Environmental Toxicology and Chemistry 35, 1656-1666.

Browne, M.A., Dissanayake, A., Galloway, T.S., Lowe, D.M., Thompson, R.C., 2008. Ingested Microscopic Plastic Translocates to the Circulatory System of the Mussel, Mytilus edulis (L.). Environmental Science \& Technology 42, 5026-5031.

Chae, Y., An, Y.-J., In press. Effects of micro- and nanoplastics on aquatic ecosystems: Current research trends and perspectives. Marine Pollution Bulletin.

Collard, F., Gilbert, B., Compère, P., Eppe, G., Das, K., Jauniaux, T., Parmentier, E., 2017. Microplastics in livers of European anchovies (Engraulis encrasicolus, L.). Environmental Pollution 229, 1000-1005.

Eriksen, M., Lebreton, L.C.M., Carson, H.S., Thiel, M., Moore, C.J., Borerro, J.C., Galgani, F., Ryan, P.G., Reisser, J., 2014. Plastic pollution in the world's oceans: more than 5 trillion plastic pieces weighing over 250,000 tons afloat at sea. PLOS ONE 9, e111913.

Espinosa, C., Cuesta, A., Esteban, M.Á., 2017. Effects of dietary polyvinylchloride microparticles on general health, immune status and expression of several genes related to stress in gilthead seabream (Sparus aurata L.). Fish \& Shellfish Immunology 68, 251-259.

Grigorakis, K., 2007. Compositional and organoleptic quality of farmed and wild gilthead sea bream (Sparus aurata) and sea bass (Dicentrarchus labrax) and factors affecting it: A review. Aquaculture 272, 55-75.

Grigorakis, S., Mason, S.A., Drouillard, K.G., 2017. Determination of the gut retention of plastic microbeads and microfibers in goldfish (Carassius auratus). Chemosphere 169, 233-238.

Güven, O., Gökdağ, K., Jovanović, B., Kıdeyş, A.E., 2017. Microplastic litter composition of the Turkish territorial waters of the Mediterranean Sea, and its occurrence in the gastrointestinal tract of fish. Environmental Pollution 223, 286-294. 
Hussain, N., Jaitley, V., Florence, A.T., 2001. Recent advances in the understanding of uptake of microparticulates across the gastrointestinal lymphatics. Advanced Drug Delivery Reviews 50, 107-142.

Jambeck, J.R., Geyer, R., Wilcox, C., Siegler, T.R., Perryman, M., Andrady, A., Narayan, R., Law, K.L., 2015. Plastic waste inputs from land into the ocean. Science 347, 768-771.

Jovanović, B., 2017. Ingestion of microplastics by fish and its potential consequences from a physical perspective. Integrated Environmental Assessment and Management 13, 510-515.

Jovanović, B., Palić, D., 2012. Immunotoxicology of non-functionalized engineered nanoparticles in aquatic organisms with special emphasis on fish-Review of current knowledge, gap identification, and call for further research. Aquatic Toxicology 118, 141151.

Koelmans, A.A., Bakir, A., Burton, G.A., Janssen, C.R., 2016. Microplastic as a vector for chemicals in the aquatic environment: critical review and model-supported reinterpretation of empirical studies. Environmental Science \& Technology 50, 3315-3326.

Koven, W., Kolkovski, S., Hadas, E., Gamsiz, K., Tandler, A., 2001. Advances in the development of microdiets for gilthead seabream, Sparus aurata: a review. Aquaculture 194, 107-121.

Lei, L., Wu, S., Lu, S., Liu, M., Song, Y., Fu, Z., Shi, H., Raley-Susman, K.M., He, D., 2018. Microplastic particles cause intestinal damage and other adverse effects in zebrafish Danio rerio and nematode Caenorhabditis elegans. Science of The Total Environment 619-620, 18.

Lozano, R.L., Mouat, J., , 2009. Marine litter in the north-east Atlantic region: assessment and priorities for response. KIMO International. ISBN 978-1-906840-26-6.

Lu, Y., Zhang, Y., Deng, Y., Jiang, W., Zhao, Y., Geng, J., Ding, L., Ren, H., 2016. Uptake and Accumulation of Polystyrene Microplastics in Zebrafish (Danio rerio) and Toxic Effects in Liver. Environmental Science \& Technology 50, 4054-4060.

Mazurais, D., Ernande, B., Quazuguel, P., Severe, A., Huelvan, C., Madec, L., Mouchel, O., Soudant, P., Robbens, J., Huvet, A., Zambonino-Infante, J., 2015. Evaluation of the impact of polyethylene microbeads ingestion in European sea bass (Dicentrarchus labrax) larvae. Marine Environmental Research 112, 78-85.

Moore, C.J., Moore, S.L., Leecaster, M.K., Weisberg, S.B., 2001. A Comparison of Plastic and Plankton in the North Pacific Central Gyre. Marine Pollution Bulletin 42, 1297-1300.

Morét-Ferguson, S., Law, K.L., Proskurowski, G., Murphy, E.K., Peacock, E.E., Reddy, C.M., 2010. The size, mass, and composition of plastic debris in the western North Atlantic Ocean. Marine Pollution Bulletin 60, 1873-1878.

O'Hagan, D., 1996. The intestinal uptake of particles and the implications for drug and antigen delivery. Journal of Anatomy 189, 477-482.

Pedà, C., Caccamo, L., Fossi, M.C., Gai, F., Andaloro, F., Genovese, L., Perdichizzi, A., Romeo, T., Maricchiolo, G., 2016. Intestinal alterations in European sea bass Dicentrarchus labrax (Linnaeus, 1758) exposed to microplastics: Preliminary results. Environmental Pollution 212, 251-256.

Phuong, N.N., Zalouk-Vergnoux, A., Poirier, L., Kamari, A., Châtel, A., Mouneyrac, C., Lagarde, F., 2016. Is there any consistency between the microplastics found in the field and those used in laboratory experiments? Environmental Pollution 211, 111-123.

Rochman, C.M., Hoh, E., Kurobe, T., Teh, S.J., 2013. Ingested plastic transfers hazardous chemicals to fish and induces hepatic stress. 3, 3263. 
Romano, N., Ashikin, M., Teh, J.C., Syukri, F., Karami, A., In press. Effects of pristine polyvinyl chloride fragments on whole body histology and protease activity in silver barb Barbodes gonionotus fry. Environmental Pollution.

Sussarellu, R., Suquet, M., Thomas, Y., Lambert, C., Fabioux, C., Pernet, M.E.J., Le Goïc, N., Quillien, V., Mingant, C., Epelboin, Y., Corporeau, C., Guyomarch, J., Robbens, J., PaulPont, I., Soudant, P., Huvet, A., 2016. Oyster reproduction is affected by exposure to polystyrene microplastics. Proceedings of the National Academy of Sciences 113, 2430.

Volkheimer, G., 1977. Persorption of particles: Physiology and pharmacology. Adv Pharmacol Chemother 14, 163-187. 

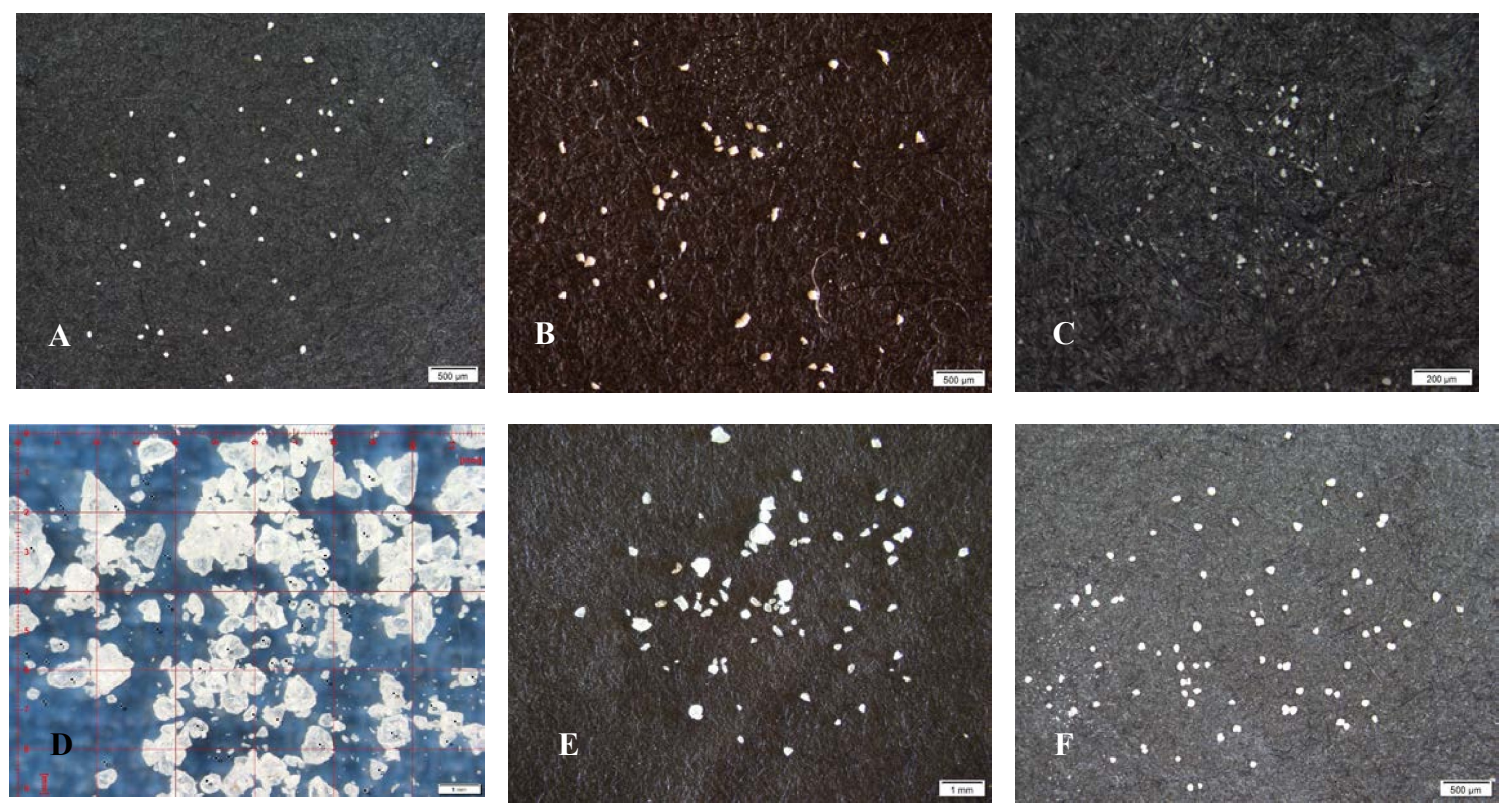

Figure 1. Photos of microplastics used in dietary exposure of S. aurata. A - polyvinyl chloride high molecular weight; B - polyamide; C - ultra-high molecular weight polyethylene; D - polystyrene; E - average molecular weight medium density polyethylene; F polyvinyl chloride low molecular weight 


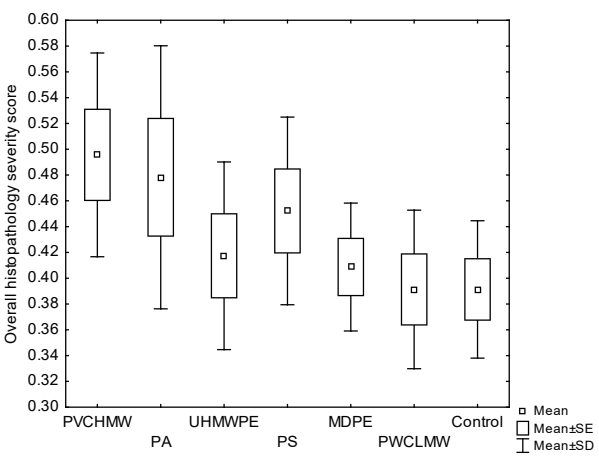

Figure 2. Histopathology severity score of $S$. aurata fed with microplastics for 45 days with $0.1 \mathrm{~g} \mathrm{~kg}^{-1}$ bodyweight. 

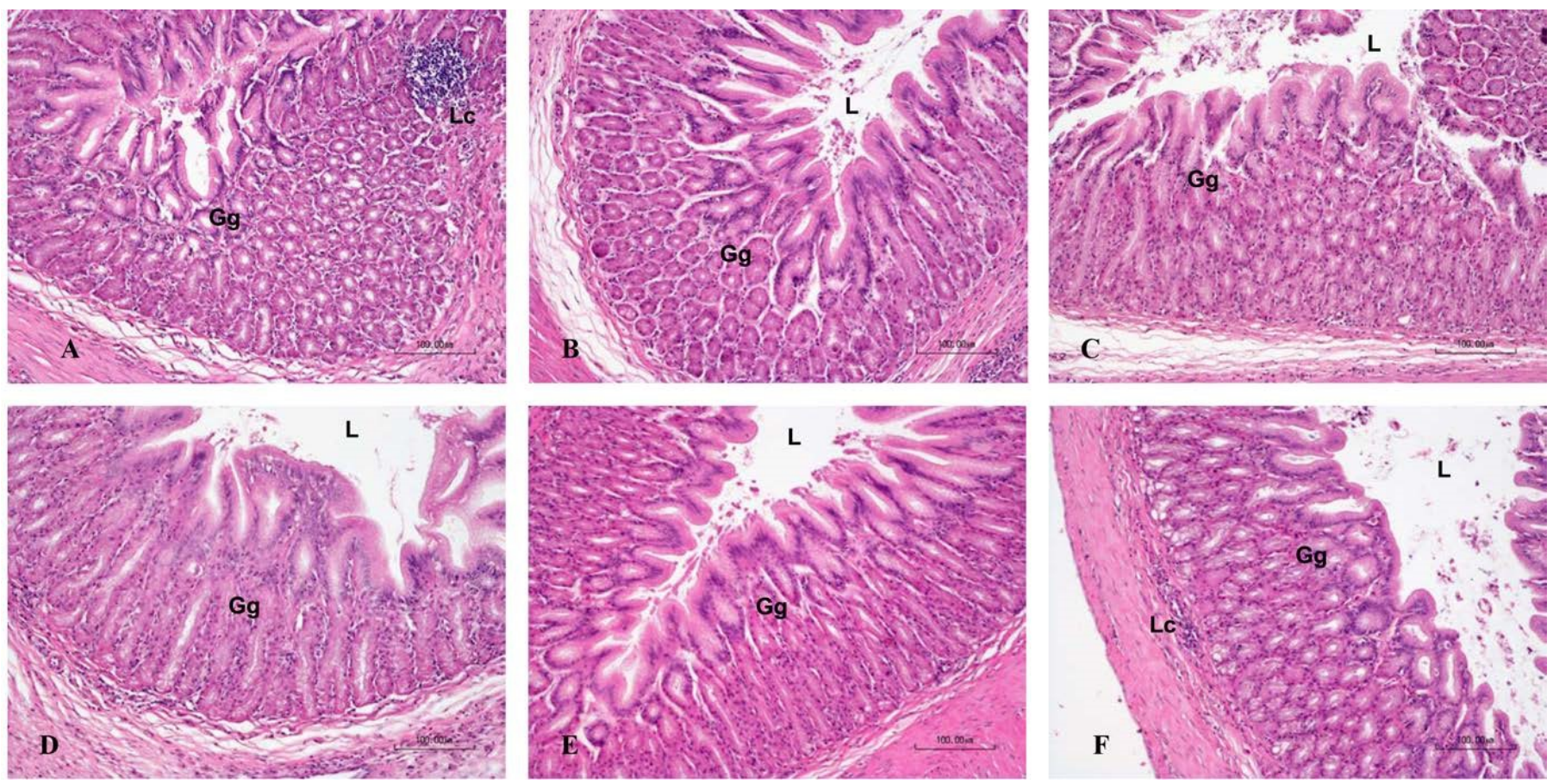

Figure 3. Representative micrographs of the stomach of $S$. aurata fed with microplastics $0.1 \mathrm{~g} \mathrm{~kg}^{-1}$ bodyweight for 45 days with. A PVCHMW; B - PA; C - UHMWPE; D - MDPE; E - PWCLMW; F - Control. Bar represents $100 \mu \mathrm{m}$. L= lumen, Gg= gastric glands, Lc $=$ lymphocytes. Note similarities to thickness and gland arrangement in the gastric mucosa of these representative photomicrographs. Small numbers of inflammatory cells were present in the lamina propria, but statistical differences in infiltrate scores were not observed. 

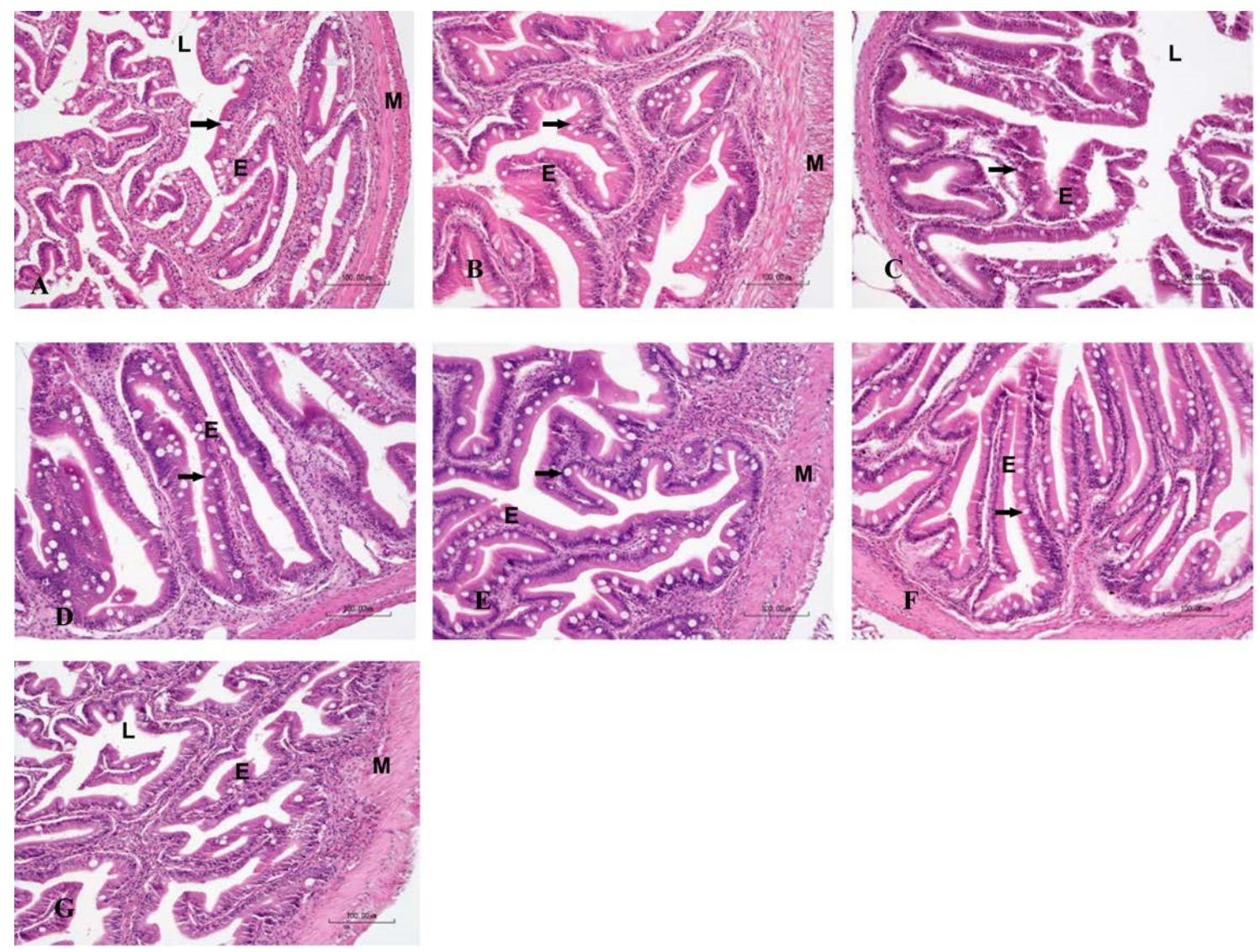

Figure 4. Representative micrographs of the intestine of $S$. aurata fed with microplastics $0.1 \mathrm{~g} \mathrm{~kg}^{-1}$ bodyweight for 45 days. A PVCHMW; B - PA; C - UHMWPE; D - PS; E - MDPE; F - PWCLMW; G - Control. Bar represents $100 \mu \mathrm{m}$. L= lumen, E= mucosal 
epithelium, $\mathrm{M}=$ muscular tunics. Note the similar morphology of the mucosa and number of goblet cells (arrows) among these representative photomicrographs. 

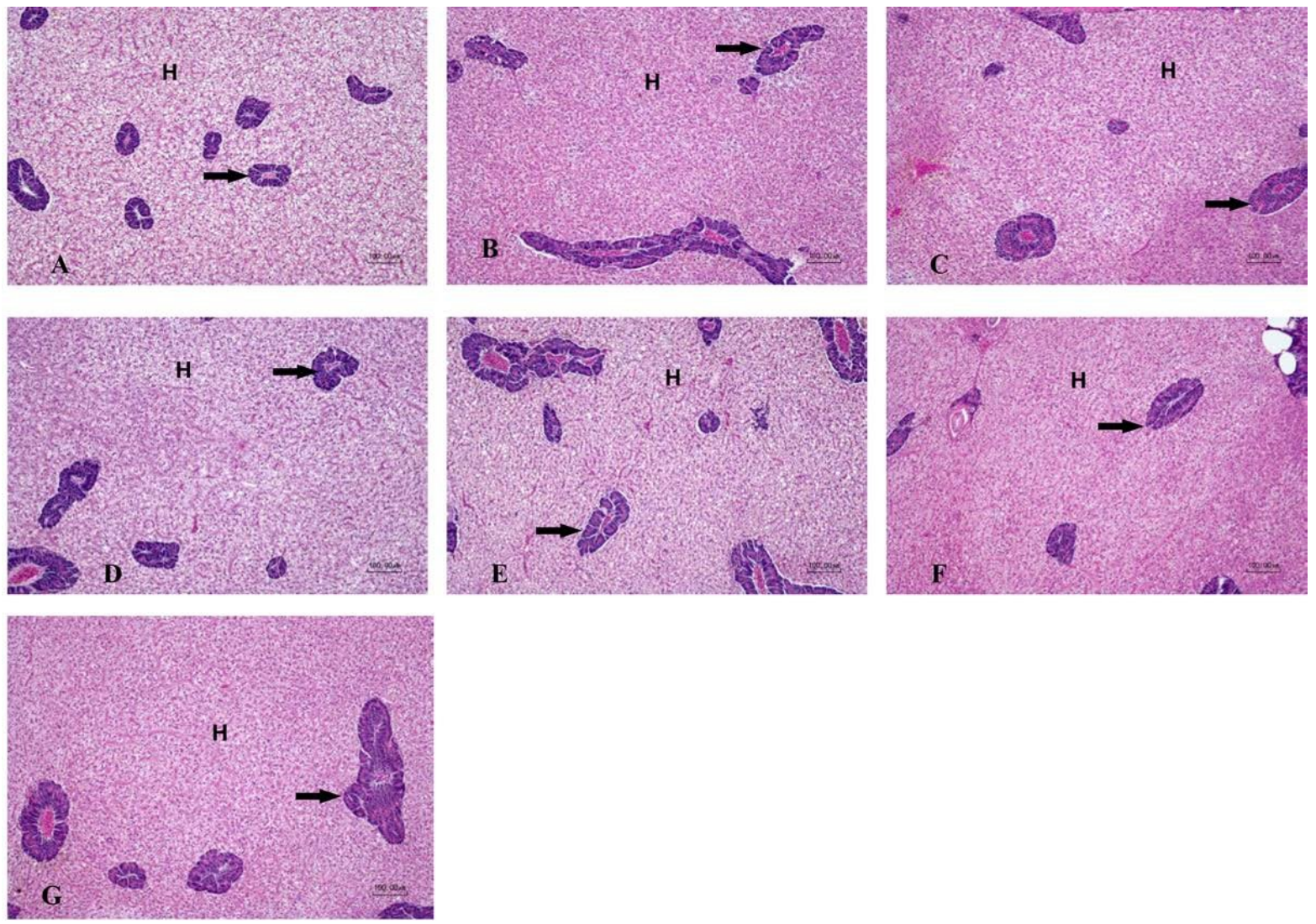

Figure 5. Representative micrographs of the liver of $S$. aurata fed with microplastics $0.1 \mathrm{~g} \mathrm{~kg}^{-1}$ bodyweight for 45 days. A PVCHMW; B - PA; C - UHMWPE; D - PS; E - MDPE; F - PWCLMW; G - Control. Bar represents $100 \mu \mathrm{m}$. Hepatic parenchyma (H) and intrahepatic pancreatic tissue (arrows) are similar in these representative photomicrographs of liver. 
Table 1. Semi-quantitative histopathology severity scale score.

\begin{tabular}{lll}
\hline Score & Severity & $\begin{array}{l}\text { Proportion of } \\
\text { affected } \\
\text { parenchyma }\end{array}$ \\
\hline 0 & No change & None \\
1 & Minimal change & Very small amount \\
2 & Mild change & Small amount \\
3 & Moderate change & Medium amount \\
4 & Severe change & Large amount \\
5 & Markedly severe & All \\
\hline
\end{tabular}


Table 2. Glucose, AST, ALT, LDH, and GGT values 45 days after the treatment or after an additional 30 days of depuration. Values are presented as mean \pm standard deviation of the mean. $\mathrm{N}=3$ for each group.

\begin{tabular}{|c|c|c|c|c|c|c|c|c|c|c|}
\hline \multirow[t]{2}{*}{ Treatment } & \multicolumn{5}{|c|}{45 days } & \multicolumn{5}{|c|}{ Additional 30 days of depuration } \\
\hline & $\begin{array}{l}\text { Glucose mg } \\
\text { dL }^{-1}\end{array}$ & $\operatorname{AST} \mathbf{U}^{-1}$ & $\operatorname{ALT} \mathbf{U ~ L}^{-1}$ & LDH U L L & GGT $\mathbf{U}^{-1}$ & $\begin{array}{l}\text { Glucose mg } \\
\text { dL }^{-1}\end{array}$ & AST $\mathbf{U}^{-1}$ & $\operatorname{ALT} \mathbf{U}^{-1}$ & LDH U L L & GGT U $L^{-1}$ \\
\hline PVCHMW & $111.3 \pm 7.8$ & $184.3 \pm 22.1$ & $16.8 \pm 6.2$ & $2307.3 \pm 234.7$ & $3.4 \pm 3.3$ & $209.3 \pm 6.5$ & $123.9 \pm 25.3$ & $23.8 \pm 15.7$ & $1688.7 \pm 393.9$ & $1.1 \pm 1.1$ \\
\hline PA & $184.7 \pm 49.5$ & $181.2 \pm 112.4$ & $28.1 \pm 14.9$ & $1757.9 \pm 940.3$ & $2.7 \pm 0.8$ & $163.0 \pm 30.4$ & $97.0 \pm 13.2$ & $9.0 \pm 2.7$ & $1738.7 \pm 377.9$ & N.A. \\
\hline UHMWPE & $176.7 \pm 41.0$ & $228.0 \pm 137.1$ & $25.4 \pm 15.5$ & $2054.9 \pm 895.3$ & $0.9 \pm 0.7$ & $192.0 \pm 70.1$ & $72.5 \pm 34.2$ & $13.8 \pm 2.7$ & $1385.7 \pm 836.2$ & $0.4 \pm 0.1$ \\
\hline PS & $147.0 \pm 20.2$ & $216.7 \pm 68.4$ & $37.4 \pm 9.6$ & $2473.0 \pm 227.4$ & $1.6 \pm 1.3$ & $229.3 \pm 33.3$ & $84.6 \pm 47.8$ & $13.2 \pm 3.9$ & $1437.0 \pm 933.1$ & N.A. \\
\hline MDPE & $104.7 \pm 8.7$ & $261.7 \pm 113.5$ & $27.3 \pm 10.8$ & $2250.0 \pm 333.1$ & $1.4 \pm 0.3$ & $222.0 \pm 62.0$ & $71.0 \pm 14.7$ & $12.1 \pm 1.9$ & $1198.3 \pm 318.7$ & $0.3 \pm 0.1$ \\
\hline PWCLMW & $133.0 \pm 36.6$ & $283.1 \pm 111.6$ & $46.6 \pm 12.8$ & $2452.1 \pm 129.5$ & $1.7 \pm 0.1$ & $196.7 \pm 15.9$ & $152.0 \pm 82.6$ & $19.5 \pm 7.0$ & $2027.7 \pm 966.5$ & $1.3 \pm 0.5$ \\
\hline Control & $146.0 \pm 16.5$ & $205.2 \pm 72.2$ & $23.3 \pm 8.9$ & $2257.1 \pm 445.2$ & $2.5 \pm 0.9$ & $146.3 \pm 38.6$ & $91.7 \pm 35.8$ & $18.5 \pm 12.5$ & $1710.3 \pm 488.1$ & $1.0 \pm 0.2$ \\
\hline $\begin{array}{l}\text { AST - asparta } \\
\text { ALT - alanine } \\
\text { LDH - lactate } \\
\text { GGT - gamma } \\
\text { N.A. - not ava }\end{array}$ & $\begin{array}{l}\text { transaminase } \\
\text { transaminase } \\
\text { dehydrogenase } \\
\text { glutamyl trans } \\
\text { lable }\end{array}$ & & & & & & & & & \\
\hline
\end{tabular}


Table 3. Retention of microplastics in various organs of $S$. aurata after daily dietary exposure to $0.1 \mathrm{mg} \mathrm{kg}^{-1}$ bodyweight. Values are presented as mean number of microplastic particles \pm standard deviation of the mean. $\mathrm{N}=15$ for each group.

\begin{tabular}{|c|c|c|c|c|}
\hline \multicolumn{3}{|c|}{ stomach } & \multicolumn{2}{|c|}{ intestine } \\
\hline $\begin{array}{l}\text { Plastic } \\
\text { type }\end{array}$ & 45 days exposure & $\begin{array}{l}45 \text { days exposure } \\
+30 \text { days } \\
\text { depuration period }\end{array}$ & 45 days exposure & $\begin{array}{c}45 \text { days } \\
\text { exposure }+30 \\
\text { days depuration } \\
\text { period }\end{array}$ \\
\hline PVCHMW & 0 & $0.13 \pm 0.35$ & $0.07 \pm 0.26$ & $0.2 \pm 0.56$ \\
\hline $\mathrm{PA}$ & $2.13 \pm 4.37$ & $0.13 \pm 0.35$ & $34.27 \pm 115$ & $0.33 \pm 0.90$ \\
\hline UHMWPE & $1.80 \pm 4.07$ & $1.80 \pm 1.82$ & $1.67 \pm 4.01$ & $0.33 \pm 0.62$ \\
\hline PS & $2.07 \pm 3.54$ & $0.20 \pm 0.56$ & $1.80 \pm 2.01$ & $0.33 \pm 0.72$ \\
\hline MDPE & $2.47 \pm 5.49$ & $4.67 \pm 18.07$ & $15.73 \pm 32.86$ & $0.07 \pm 0.26$ \\
\hline \multirow[t]{2}{*}{ PWCLMW } & $5.4 \pm 19.56$ & $0.40 \pm 0.91$ & $9.27 \pm 22.67$ & $6.2 \pm 24.01$ \\
\hline & \multicolumn{2}{|c|}{ liver } & \multicolumn{2}{|c|}{ muscle } \\
\hline $\begin{array}{l}\text { Plastic } \\
\text { type }\end{array}$ & 45 days exposure & $\begin{array}{l}45 \text { days exposure } \\
\quad+30 \text { days } \\
\text { depuration period }\end{array}$ & 45 days exposure & $\begin{array}{c}45 \text { days } \\
\text { exposure }+30 \\
\text { days depuration } \\
\text { period }\end{array}$ \\
\hline PVCHMW & 0 & $1.00 \pm 3.87$ & 0 & 0 \\
\hline PA & 0 & 0 & 0 & 0 \\
\hline UHMWPE & $0.07 \pm 0.26$ & 0 & 0 & $0.07 \pm 0.26$ \\
\hline PS & $0.07 \pm 0.26$ & 0 & 0 & 0 \\
\hline MDPE & $0.60 \pm 2.06$ & 0 & 0 & 0 \\
\hline PWCLMW & 0 & 0 & 0 & 0 \\
\hline
\end{tabular}

